\title{
Two isozymes of branched-chain amino acid aminotransferase in submandibular gland of the monkey
}

\author{
Shigenori Kawagishi \\ Department of Stomatology, Kyushu Dental College \\ 2-6-1 Manazuru, Kokurakita-ku, Kitakyushu 803, Japan
}

[Accepted for publication: May 21, 1984]

Key words: branched-chain amino acid/aminotransferase/submandibular gland

\begin{abstract}
Crude extract from the submandibular gland of a macaque monkey contained a high activity of branched-chain amino acid aminotransferase. Two isozymes of aminotransferase were detected in the crude extract and separated by DEAE-Sepharose CL-6B column chromatography. The isozymes were partially purified and the properties of the isozymes studied. These isozymes were different in their affinity for substrates and the velocity in reverse reaction beside their behaviors on the chromatographies. Distribution of the isozymes in other monkey tissues was also examined.
\end{abstract}

\section{Introduction}

Branched-chain amino acids, leucine, isoleucine and valine, are primarily degraded in extra-hepatic tissues, although most of the indispensable amino acids are catabolized in the liver ${ }^{1,2)}$. Skeletal muscle rapidly degrades these branched-chain amino acids, and muscle is probably the primary site of their degradation ${ }^{3-9)}$. The oxidation of leucine supplies appreciable amount of ATP to muscle, especially in starvation ${ }^{4}$. Adipose tissue also actively degrades leucine: leucine can be utilized as a precursor of fatty acid and sterol and also serves as a source of nitrogen for synthesis of glutamine, glutamate and alanine ${ }^{10-12)}$.

The first step in the catabolic pathway of these amino acids is catalysed by a branchedchain amino acid: 2-oxoglutarate aminotransferase (EC 2.6.1.6). The aminotransferase activity is high in extra-hepatic tissues and low in the liver ${ }^{2,13)}$. Previous paper has reported that crude extracts from submandibular glands of several animals con- tained high activities of branched-chain amino acid aminotransferase comparable to those from the heart etc. ${ }^{14)}$ The enzyme of rat submandibular gland was partially purified; the properties of the purified enzyme suggested that it was the same type as that from the heart. The study also indicated the occurrence of two types of enzyme only in the macaque monkey submandibular gland among the animals examined. In the present study, two isozymes of aminotransferase were partially purified from the macaque monkey submandibular gland and characterized.

\section{Materials and Methods}

\section{Animal}

Monkeys (Macaca irus) were maintained on laboratory diet ad libitum.

\section{Preparation of tissue extract}

All procedures were carried out at $0-4^{\circ} \mathrm{C}$. Monkeys were anaesthized with ethyl ether, and killed by bleeding. The various tissues were removed, minced and homogenized in a Ultra-Disperser (Model LK-21, Yamato 
Inc., Japan) for $1 \mathrm{~min}$ with 5 vol. of $5 \mathrm{mM}$ potassium phosphate buffer $(\mathrm{pH}$ 7.5)-0.2 $\mathrm{mM}$ pyridoxal phosphate. Each homogenate was sonicated for $30 \mathrm{~s}$ at $10 \mathrm{KHz}$, squeezed through gauze and then centrifuged at $100,000 \times g$ for $40 \mathrm{~min}$. The resulting supernatants were referred to as the crude tissue extracts.

Separation of isozymes I and III of aminotransferase

All manipulations were carried out at 0 $4^{\circ} \mathrm{C}$. The crude extract from submandibular glands $(7.0 \mathrm{~g}$ ) was prepared as above (Step 1) and treated with ammonium sulphate. A fraction precipitated between 25 and $75 \%$ $\left(\mathrm{NH}_{4}\right)_{2} \mathrm{SO}_{4}$ saturation was collected by centrifugation, dissolved in $5 \mathrm{mM}$ potassium phosphate buffer ( $\mathrm{pH}$ 8.2)-1 mM EDTA$2 \mathrm{mM}$ 2-mercaptoethanol-0.01 $\mathrm{mM}$ pyridoxal phosphate, and dialysed against the same buffer (Step 2). These concentrations of EDTA and 2-mercaptoethanol were added to all buffers used during the purification and pyridoxal phosphate was contained only in dialysis buffers. The enzyme solution was applied to a column $(2.0 \times 18 \mathrm{~cm})$ of DEAESepharose CL-6B equilibrated with the same buffer (Fig. 1). The column was washed with $180 \mathrm{ml}$ of the same buffer and eluted with a linear concentration gradient of 5$500 \mathrm{mM}$ phosphate $(680 \mathrm{ml})$. Fractions of $18-\mathrm{m} l$ were collected. The activity of aminotransferase was eluted from the column in two fractions. The first fraction was eluted at about $80 \mathrm{mM}$ phosphate and the second fraction at about $280 \mathrm{mM}$ phosphate. The first fraction (fractions 12-17) was pooled, concentrated by ultrafiltration, dialysed against $5 \mathrm{mM}$ potassium phosphate buffer, $\mathrm{pH} 7.5$ and used as isozyme I fraction in further purification (Step 3). On the other hand, the second fraction (fractions 28-35) was also pooled, concentrated by ultrafiltration, dialysed against $10 \mathrm{mM}$ potassium phosphate buffer, $\mathrm{pH} 6.8$ and used as isozyme III fraction in further purification (Step $3^{\prime}$ ).

\section{Purification of isozyme I}

The isozyme I fraction obtained from DEAE-Sepharose CL-6B column chromatography was subjected to isoelectric focusing on a $110 \mathrm{ml}$ column (LKB) according to the method of Vesterberg and Svensson ${ }^{15)}$. Focusing was carried out on a pH 3-10 Pharmalyte gradient for $40 \mathrm{~h}$ at $500 \mathrm{~V}$. The

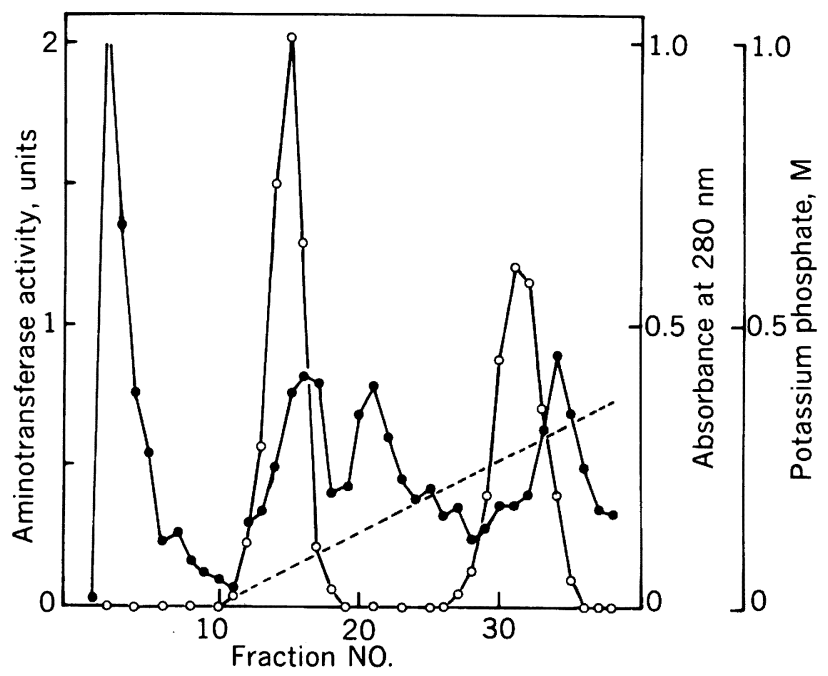

Fig. 1 Elution profile of aminotransferase on DEAESepharose. (O), Aminotransferase activity; (0), protein monitored by the absorbance at $280 \mathrm{~nm}$; $(--)$, potassium phosphate concentration. 
eluate was collected in 2-m $l$ fractions and the activity and $\mathrm{pH}$ of each fraction were measured. Enzyme activity was detected at $\mathrm{pH} 7.1$ in one peak. The active fractions 28-31 were pooled, concentrated by ultrafiltration and applied to a column $(2.5 \times$ $100 \mathrm{~cm}$ ) of Sephacryl S-200 in $50 \mathrm{mM}$ potassium phosphate buffer ( $\mathrm{pH} 7.5)-10 \%$ glycerol. The column was eluted at flow rate of $25 \mathrm{ml} / \mathrm{h}$ with the same buffer and $3-\mathrm{m} l$ fractions were collected. The active fractions of enzyme emerging in a single peak at fractions 99-114 were pooled, concentrated by ultrafiltration and dialysed against $10 \mathrm{mM}$ potassium phosphate buffer, $\mathrm{pH} 6.8$ (Step 4 ). The dialysed solution was applied to a column $(1.0 \times 8.8 \mathrm{~cm})$ of hydroxyapatite equilibrated with the same buffer. The column was washed with $20 \mathrm{ml}$ of the same buffer and then eluted with a linear concentration gradient of $10-400 \mathrm{mM}$ phosphate, $\mathrm{pH} 7.8(100 \mathrm{ml})$. Fractions of $2.6 \mathrm{ml}$ were collected. The activity was eluted from the column at about $130 \mathrm{mM}$ phosphate. The active fractions 18-29 were pooled, concentrated by ultrafiltration (Step 5) and used as the partially purified preparation of isozyme I from the monkey submandibular gland.

\section{Purification of isozyme III}

The isozyme III fraction resulting from DEAE-Sepharose column chromatography was applied to a column $(2.0 \times 9.0 \mathrm{~cm})$ of hydroxyapatite equilibrated with $10 \mathrm{mM}$ potassium phosphate buffer, $\mathrm{pH}$ 6.8. After washing with $90 \mathrm{ml}$ of the same buffer, the enzyme was eluted with a $180-\mathrm{m} l$ linear gradient of $10-400 \mathrm{mM}$ phosphate, $\mathrm{pH} 7.8$. Fractions of $5.7 \mathrm{ml}$ were collected. The activity was eluted from the column at about $80 \mathrm{mM}$ phosphate. The active fractions 23 29 were pooled and concentrated by ultrafiltration (Step $4^{\prime}$ ). The concentrated solution was applied to a column $(2.5 \times 100 \mathrm{~cm})$ of Sephacryl S-200 in $50 \mathrm{mM}$ potassium phosphate buffer ( $\mathrm{pH}$ 7.5)-10\% glycerol. The column was eluted with the same buffer and $3-\mathrm{m} l$ tractions were collected. A single aminotransferase activity peak was obtained. The active fractions $81-97$ were pooled, concentrated by ultrafiltration (Step $5^{\prime}$ ) and used as the partially purified preparation of isozyme III.

\section{Assay of enzyme activity}

For the assay of aminotransferase activity, a standard reaction mixture, containing 6 $\mu \mathrm{mol}$ of L-amino acid, $1 \mu \mathrm{mol}$ of $\alpha$-ketoglutarate, $0.02 \mu \mathrm{mol}$ of pyridoxal phosphate, 20 $\mu \mathrm{mol}$ of 2-mercaptoethanol, $10 \mu \mathrm{mol}$ of potassium pyrophosphate buffer ( $\mathrm{pH}$ 8.2) and enzyme in a total volume of $0.3 \mathrm{ml}$, was incubated for $30 \mathrm{~min}$ at $37^{\circ} \mathrm{C}$ and the branched-chain $\alpha$-keto acids formed were measured as previously described ${ }^{14)}$. One enzyme unit is defined as that amount of enzyme which catalyses the formation of $1 \mu \mathrm{mol}$ of $\alpha$-keto acid/min under standard assay conditions. For routine assay, leucine was used as an amino acid unless otherwise specified. In a reverse reaction, the $\alpha$ ketoglutarate formed was determined as previously described ${ }^{14)}$.

\section{Other materials and methods}

DEAE-Sepharose CL-6B, Sephacryl S-200 and Pharmalyte were purchased from Pharmacia Fine Chemicals. Hydroxyapatite was obtained from Seikagaku Kohgyo (Tokyo, Japan). Protein was assayed by the method of Lowry et al. ${ }^{16)}$ All chemicals were obtained from commercial sources.

\section{Results and Discussion}

Table 1 shows the distribution of branchedchain amino acid aminotransferase activity in various tissues of the monkey. Extract from the submandibular gland exhibited a high activity of aminotransferase comparable to those from stomach, hcart and kidney. The same result was obtained in the estimation using isoleucine or valine as a substrate.

The aminotransferase activity in the crude extract from submandibular gland was separated into two fractions by means of chromatography on a DEAE-Sepharose CL-6B column as shown in Fig. 1. The activity which was eluted at lower concentration of phosphate was tentatively designated as isozyme I; the activity eluted at higher concen- 
Table 1 Aminotransferase distribution in various tissues of the monkey

\begin{tabular}{lcccr}
\hline & & \multicolumn{2}{c}{$\begin{array}{c}\text { Distribution } \\
\text { Tistivity }\end{array}$} \\
\cline { 3 - 5 } & $\begin{array}{c}\text { of } \\
\text { of } \begin{array}{c}\text { units/g } \\
\text { wet tissue }\end{array}\end{array}$ & I & $\begin{array}{c}\text { II }^{c} \\
(\%)\end{array}$ & III \\
\hline Submandibular gland & 2.49 & 55 & & 45 \\
Brain & 0.43 & 10 & & 90 \\
Liver & 0.08 & 15 & 85 & \\
Lung & 0.71 & 50 & & 50 \\
Spleen & 0.47 & 75 & & 25 \\
Stomach & 3.00 & 85 & & 15 \\
Heart & 2.14 & 100 & & \\
Kidney & 2.10 & 100 & & \\
Tongue & 0.79 & 100 & & \\
Skeletal muscle & 0.39 & 100 & & \\
\hline
\end{tabular}

$a$ The crude extracts obtained from the various tissues were incubated under the standard assay conditions.

$b$ The crude extracts were fractionated by ammonium sulphate and applied to DEAESepharose CL-6B column chromatography. The procedures were the same as those in the purification of enzyme from submandibular gland.

c Isozyme II was eluted from the column at about $250 \mathrm{mM}$ phosphate and specific for leucine only.

tration of phosphate, isozyme III. The both isozyme fractions were further purified. The result of the purification is summarized in Table 2. In each isozyme preparation, the ratios among the specific activities for the three branched-chain amino acids remained constant during enzyme purification.

The activity of isozyme III fraction obtained from DEAE-Sepharose CL-6B column chromatography was inactivated during isoelectric focusing which availed in the purification of isozyme I. When the crude extract was directly subjected to isoelectric focusing, two activity peaks at $\mathrm{pH} 4.3$ and 7.1 were detected, suggesting that the isoelectric point of isozyme III is 4.3.

The optimum $\mathrm{pH}$ for both aminotransferase activities in $33.3 \mathrm{mM}$ potassium pyrophosphate was near 8.2 for all three amino acids. The apparent $\mathrm{Km}$ values for substrates of the two isozymes were different (Table 3). Both enzyme reactions were accelerated by SH-reagent. The maximum activity of isozyme I was achieved in about $15 \mathrm{mM}$ 2-mercaptoethanol or about $4 \mathrm{mM}$ dithiothreitol. Activation of isozyme III by 2-mercaptoethanol or dithiothreitol reached a maximum at about $10 \mathrm{mM}$ or $3 \mathrm{mM}$, respectively. The activities of both isozymes were completely inhibited in the presence of $0.1 \mathrm{mM} p$-chloromercuribenzoate or $1 \mathrm{mM}$ iodoacetoamide. The above results indicate that both isozymes are SH-enzymes.

Table 4 shows that there was considerable formation of ketodicarboxylic acid from Lglutamate as the keto acids corresponding to the branched-chain amino acids were incubated with glutamate and enzyme. This indicates that the transamination of each isozyme is reversible. Then, the ratios of the formation of ketomonocarboxylic acid and

Table 2 Purification of isozymes I and III

\begin{tabular}{cclrcc}
\hline Isozyme & Step & Fraction & $\begin{array}{c}\text { protein } \\
(\mathrm{mg})\end{array}$ & $\begin{array}{c}\text { Total } \\
\text { activity } \\
\text { (units) }\end{array}$ & $\begin{array}{c}\text { Specific } \\
\text { activity } \\
\text { (units/mg) }\end{array}$ \\
\hline \multirow{4}{*}{ I } & 1. & Crude extract & 1335.2 & 17.36 & 0.013 \\
& 2. & Ammonium sulphate & 695.4 & 15.30 & 0.022 \\
& 3. & DEAE-Sepharose & 38.7 & 7.00 & 0.181 \\
& 4. & Isoelectric focusing and & & & \\
& & Sephacryl S-200 & 5.7 & 2.65 & 0.465 \\
III & 5. & Hydroxyapatite & 2.0 & 2.02 & 1.010 \\
& $3^{\prime}$ & DEAE-Sepharose & 42.3 & 5.86 & 0.139 \\
& $4^{\prime}$ & Hydroxyapatite & 24.3 & 4.89 & 0.201 \\
& $5^{\prime}$ & Sephacryl S-200 & 5.8 & 3.88 & 0.669 \\
\hline
\end{tabular}


Table 3 Apparent $\mathrm{K} m$ values

\begin{tabular}{lcc}
\hline \multirow{2}{*}{ Substrate } & \multicolumn{2}{c}{$\mathrm{K} m(\mathrm{mM})$} \\
\cline { 2 - 3 } & Isozyme I & Isozyme III \\
\hline L-Leucine & $0.65-0.70$ & $0.30-0.35$ \\
L-Isoleucine & $0.65-0.70$ & $0.30-0.35$ \\
L-Valine & $1.80-1.85$ & $1.05-1.10$ \\
$\alpha$-Ketoglutarate & $1.40-1.45$ & $1.40-1.45$ \\
\hline
\end{tabular}

ketodicarboxylic acid in the two aminotransferase reactions were apparently different; the velocity of reverse reaction of isozyme III was larger than that of isozyme I. The lower formation of ketodicarboxylic acid from $\mathrm{D}$ - $\alpha$-keto- $\beta$-methylvalerate than those from two other branched-chain keto acids, which was observed in the study on aminotransferase from the rat submandibular gland, may be due to use of a D and $\mathrm{L}$ stereoisomic mixture as a substrate.

Distribution of isozymes of branched-chain amino acid aminotransferase in other various tissues of the monkey was also examined. The result is shown in Table 1 . Isozyme I was contained in all the tissues examined. On the other hand, isozyme III was located in a narrower range. Isozyme II in the liver was specific for leucine only and its properties are on study.

Ogawa, Yokojima and Ichihara showed that there are three isozyme types of branched-chain amino acid aminotransferase in the rat tissues and that they are separated by DEAE-cellulose column chromatography ${ }^{17)}$. Isozyme I is widely distributed in various tissues and isozyme II is present only in the liver. Isozyme III occurs in the brain, ovary, placenta and hepatomas cell. In the rat submandibular gland, type of isozyme I only have been detected ${ }^{14)}$. Distribution of isozymes, especially isozyme III, is variable among animal species. Study on distribution and physiological roles of isozymes in submandibular gland seems be interesting.

Table 4 Reversibility of the reaction

\begin{tabular}{|c|c|c|c|c|c|}
\hline & \multirow{2}{*}{ Substrate } & \multicolumn{4}{|c|}{ Activity $(\mathrm{nmol} / 30 \mathrm{~min})$} \\
\hline & & \multicolumn{2}{|c|}{$\begin{array}{l}\alpha \text {-Ketomonocarboxylate } \\
\text { formed }\end{array}$} & \multicolumn{2}{|c|}{$\begin{array}{l}\alpha \text {-Ketodicarboxylate } \\
\text { formed }\end{array}$} \\
\hline Amino acid & Keto acid & Isozyme I & Isozyme III & Isozyme I & Isozyme III \\
\hline L-Leucine & $\alpha$-Ketoglutarate & 74 & 67 & & \\
\hline L-Isoleucine & $\alpha$-Ketoglutarate & 81 & 77 & & \\
\hline L-Valine & $\alpha$-Ketoglutarate & 67 & 77 & & \\
\hline L-Glutamate & $\alpha$-Ketoisocaproate & & & 31 & 50 \\
\hline L-Glutamate & D- $\alpha$-Keto- $\beta$-methylvalerate ${ }^{a}$ & & & 9 & 12 \\
\hline L-Glutamate & $\alpha$-Ketoisovalerate & & & 28 & 50 \\
\hline
\end{tabular}

$a$ D-L Isomeric mixture.

抄録：サル顎下腺の粗抽出液中に分岐鎖アミノ酸アミノ基転移酵素の高い活性が存在していた。粗抽出 液中には分岐鎖アミノ酸アミノ基転移酵素の二種のアイソザイムが検出され，それらは DEAE一セファ ローズカラムクロマトグラフィーにより分離された。各々のアイソザイムは部分精製され, その諸性質が 比較検討された。両アイソザイムは分岐鎖アミノ酸いずれにも作用し似たような性質を示すが, クロマト グラフィー上の挙動の相違に加えて, 基質に対する親和性および逆反応の際の速度が異なることが認めら れた。

サルの他の組織におけるアイソザイムの分布についても検討が加えられた。 


\section{References}

1) Miller, L. L.: The role of the liver and non-hepatic tissues in the regulation of free amino acid levels in the blood. In: Amino Acid Pools (Edited by Holden, J. T.). p. 708-721, Elsevier, Amsterdam, 1961.

2) Ichihara, A. and Koyama, E.: Transaminase of branched chain amino acids. I. Branched chain amino acids- $\alpha$-ketoglutarate transaminase. J. Biochem. (Tokyo) 59: 160-169, 1966.

3) Buse, M. G., Biggers, J. F., Friderici, K. H. and Buse, J. F.: Oxidation of branched chain amino acids by isolated hearts and diaphragms of the rat. The effect of fatty acids, glucose, and pyruvate respiration. J. Biol. Chem. 247: 8085-8096, 1972.

4) Meikle, A. W. and Klain, G. J.: Effect of fasting and fasting-refeeding on conversion of leucine into $\mathrm{CO}_{2}$ and lipids in rats. Am. J. Physiol. 222: 1246-1250, 1972.

5) Odessey, R. and Goldberg, A. L.: Oxidation of leucine by rat skeletal muscle. Am. J. Physiol. 223: 1376-1383, 1972.

6) Chang, T. W. and Goldberg, A. L.: The metabolic fates of amino acids and the formation of glutamine in skeletal muscle. J. Biol. Chem. 253: 3685-3695, 1978.

7) Goldberg, A. L. and Chang, T. W.: Regulation and significance of amino acid metabolism in skeletal muscle. Fed. Proc. 37: 2301-2307, 1978.

8) Odessey, R. and Goldberg, A. L.: Leucine degradation in cell-free extracts of skeletal muscle. Biochem. J. 178: 475-489, 1979.

9) Hutson, S. M., Zapalowski, C., Cree, T. C. and Harper, A. H.: Regulation of leucine and $\alpha$-ketoisocaproic acid metabolism in skeletal muscle. Effects of starvation and insulin. J. Biol. Chem. 255: 2418-2426, 1980.

10) Rosenthal, J., Angel, A. and Farkas, J.: Metabolic fate of leucine: a significant sterol precursor in adipose tissue and muscle. Am. J. Physiol. 226: 411-418, 1974.

11) Tischler, M. E. and Goldberg, A. L.: Leucine degradation and release of glutamine and alanine by adipose tissue. J. Biol. Chem. 255: 8074-8081, 1980.

12) Frerman, F. E., Sabran, J. L., Taylor, J. L. and Grossberg, S. E.: Leucine catabolism during the differentiation of 3T3-L1 cells. Expression of a mitochondrial enzyme system. J. Biol. Chem. 258: 7087-7093, 1983.

13) Taylor, R. T. and Jenkins, W. T.: Leucine aminotransferase. II. Purification and characterization. J. Biol. Chem. 241: 4396-4405, 1966.

14) Kawagishi, S. and Shinozaki, F.: Branchedchain amino acid aminotransferase in submandibular gland of the rat. Archs. Oral Biol. 28: 303-306, 1983.

15) Vesterberg, O. and Svensson, H.: Isoelectric fractionation, analysis and characterization of ampholites in natural $\mathrm{pH}$ gradients. IV. Further studies on the resolving power in connection with separation of myoglobins. Acta Chem. Scand. 21: 839-844, 1966.

16) Lowry, O. H., Rosenbrough, N. J., Farr, A. L. and Randall, R. J.: Protein measurement with a folin phenol reagent. J. Biol. Chem. 211: 839-844, 1951.

17) Ogawa, K., Yokojima, A. and Ichihara, A.: Transaminase of branched chain amino acids. VII. Comparative studies on isozymes of ascites hepatoma and various normal tissues of rat. J. Biochem. (Tokyo) 68: 901-911, 1970. 